\title{
EFFECT OF ENVIRONMENTAL PERFORMANCE, ENVIRONMENTAL DISCLOSURE AND PUBLIC VISIBILITY ON ECONOMIC PERFORMANCE OF COMPANIES LISTED IN INDONESIA STOCK EXCHANGE DURING PERIOD OF 2015-2016
}

\author{
Rachmawati C. ${ }^{*}$, Agustia D., Soewarno N. \\ University of Airlangga, Indonesia \\ *E-mail: rachmawaticindy@gmail.com
}

\begin{abstract}
This study aims to determine the relationship between the environmental performance, environmental disclosure and public visibility on economic performance. This study used a sample of companies listed on the stock exchanges in Indonesia in 2015-2016 and there were 66 companies who met the study criteria. Multiple linear regressions were used to test the hypothesis in this study. The results of this study indicate that the environmental disclosure negative significant effect on the economic performance visibility whereas public variables have a significant effect negatively on economic performance, but for environmental performance variables showed significant results on economic performance.
\end{abstract}

\section{KEY WORDS}

Public service, disclosure, economic effect, performance.

Living in a country that has the world's largest archipelago with 17,000 islands located between two oceans and two continents make the country Indonesia ranks fourth as the country with the largest population in the world. On population much that Indonesia is blessed with abundant wealth in the form of biological wealth. However, in Indonesia now that deforestation was well above normal limits. About $2 \%$ per year in Indonesian forests damaged by illegal logging and the lack of concern for the community to participate in helping the government in preserving the forest. The impact of forest destruction is the destruction of ecosystems and natural resources resulting in natural disasters such as floods, landslides, and global warming. Indonesian forests are the lungs of the world,

The pollution caused by vehicle emissions, human waste, and industrial waste pose a direct threat to human health and welfare. The heavy influence of air pollution, environmental pollution, or also called the waste caused by companies who do not have a sense of high concern for the environment. Here's an example of environmental issues conducted by several companies.

Companies are now not only faced with the problem of the business goals, but the company is also required to complete and fix the environmental problems that exist around their company. The business world a lot rests on the concept of capitalism that is more about maximizing the prosperity of the owners of capital rather than the comfort of other stakeholders (Kemal Ceka 2017).

As a result, profit established as the highest goal and looked at other aspects as priority underneath. Environmental problems currently a very competitive issue in the business world. Environmental issues lately many steal the company, so the company seeks to make improvements by increasing the sense of responsibility to the environment surrounding the company. To realize accountability in the corporate environment using the essential elements of the environmental costs. This prompted the company to have a financial information system that can help the company's management in addressing environmental problems. Accounting as a discipline raised the issue of social and environmental issues through the mechanism of social and environmental accounting (Sara Segura 2017).

The concept of environmental accounting has actually been started to develop since the 1970s in Europe. Due to the pressure instead of government agencies and increasing environmental awareness among the people who urged companies applying environmental 
management is not just a business for the sake of industrial activity only (Yongxiang Wang, 2017).

Examples of companies that can cause damage to the environment is PT Newmont Nusa Tenggara dangerous to use technology in the ocean, that submarine tailings disposal (Submarine Tailings Disposal) system, which has resulted in pollution in Buyat Bay, North Sulawesi, PT Newmont Minahasa Raya. In fact, the survey results KLH conducted in September 2004 in the area of Tongo Sejorong, Benete and lava, West Nusa Tenggara, showed approximately $76-100 \%$ of respondents fishermen stated that their incomes declined after Newmont dispose of tailings into the bay Senunu, which has up to 120,000 tonnes of tailings per day, or 60 times the amount of tailings Newmont in Buyat bay.

Empirical research on the relationship between environmental performance, environmental disclosure and public visibility to economic performance has generally been considered the strength of the relationship between these variables. Research conducted by Tiansen Liu (2016) says that the effect on the Economic Performance Environmental Performance. Research conducted by Keunyeob Ohb, Insoo Han (2017) states that global environmental management positively influences the company's intention environmental innovations. Environmental innovation behavior in general has a greater effect on the environment performance of the economy's performance.

\section{HYPOTHESIS DEVELOPMENT}

Legitimacy theory. According to Deegan and Rankin (1996), legitimacy theory states that companies continually have to ensure that their activities are in accordance with the norms enshrined society, so that the organization or the company can be accepted by outsiders (legitimized). Because in addition to the rights of investors, other things that also need to be considered by the organization is the rights of the public, especially those in the region, organizational or company is operating.

The basis of the theory of legitimacy is the presence of "social contract" between the company and the communities that surround the company's operations, and how companies in the use of economic resources (Ghozali and Chariri, 2007). So every company has an implicit contract with society to carry out its activities in accordance with the norms prevailing in society. If the contract is violated by the company, it would appear the rejection of society which can certainly result in losses for the company.

Theory Triple Bottom Lines. The concept of CSR is growing and the development of the CSR concept so many theories that emerged expressed regarding CSR. The famous one is the theory of the triple bottom line where this theory the view that if a company wants to survive, then it must pay attention to "3P" (Wibisono: 2007).

Environmental accounting. Environmental accounting is to identify, measure and allocation of environmental costs and integration costs into business decision making and communicating the results to the stockholders of the company (Rossje: 2006).

The concept of environmental accounting reporting had developed in the 1970s in Europe. Due to pressure from non-governmental organizations and the growing environmental awareness society that urged companies implementing environmental management, not only focus on business sectors (Djogo, 2006: 1).

Each company's operational activities aim to make a profit as possible. In general, management reduce production costs as much as possible. During this time the cost of environmental damage is considered as externalities to the activities of the company. Therefore, environmental accounting is applied as a new technique that is used to identify the cost of environmental damage and report it as the cost of production is more accurate (Purwanto, 2000)

Implementation of environmental accounting helps companies to determine the actual production costs to take into account the environmental costs arising from the operations of the company. By knowing the costs actually occurred, management will be able to have a basis for making more accurate decisions, especially with regard to environmentally friendly processes and efficiency cost-effective production. 
Effect of Environmental Performance, Environmental Disclosure and Public Visibility Toward Economic Performance. Research conducted by Keunyeob Ohb, Insoo Han (2017) states that the behavior control environment and global environmental management to positively affect the company's intention environmental innovations. Environmental Behavior of innovation in general has a greater effect on the environment performance of the economy's performance. The environmental performance was also positively affect economic performance. Innovation in product design improves environmental performance at the national level models, and in Shandong, Jiangsu and Shanghai.

Companies exaggerate the level of their CSR practices to create a more positive corporate image to their stakeholders (Kemal Ceka, 2017). Companies registered in China with the center of the state ownership are encouraged to create social and environmental disclosure pursuant SASAC recommendations, but these companies do not show a substantial difference in social and environmental disclosure compared with other Chinese listed companies. The involvement of the Big Four in the financial audit was also unsuccessful substantial differences in social and environmental disclosure (Indra Abeysekera, 2014)

Disclosure of environmental information would benefit the market as well as the ability to benefit from its investment in Indonesia environmental improvements. However, the findings for the other three variables, namely ROA, ROE, and EPS do not show any significant correlation between the total environmental disclosure (Inaliah Mohd Ali, 2016). Environmental Performance positive effect on the Financial Performance (Economic Performance). Social Performance positive influence on Institutional Owning (Robin W, Roberts, 2017). Green Accounting proven to improve financial performance. Government regulation is an important approach to ensuring CER. That the Government of China should further improve the legal and regulatory environment, strengthen government supervision, urging the company to do more CERs.

The impact of mass media, the ability to induce cognitive change among individuals, has been dubbed the agenda setting function of mass communication. Herein lies the most important effect of mass communication, media capabilities for structuring the world for us (JUN Cheng, Yuyu Liu, 2018). The audience not only learns the news and other things through the media, but also learns how much importance is given to an issue or topic of how the mass media gives emphasis to the topic. Not all customers could see PROPER score, as well as the Environmental Disclosure via the annual report can be rarely touched by the customer. Then the media become the most powerful tool to proclaim the company's environmental activities to customers because this medium has great potential to be read or seen by the customer. Coverage by great media can influence the opinion of the customer to remain loyal or will move to the company committed to the environment (JUN Cheng, Yuyu Liu, 2018)

Based on the formulation of the problem under study, the hypothesis proposed in this study are:

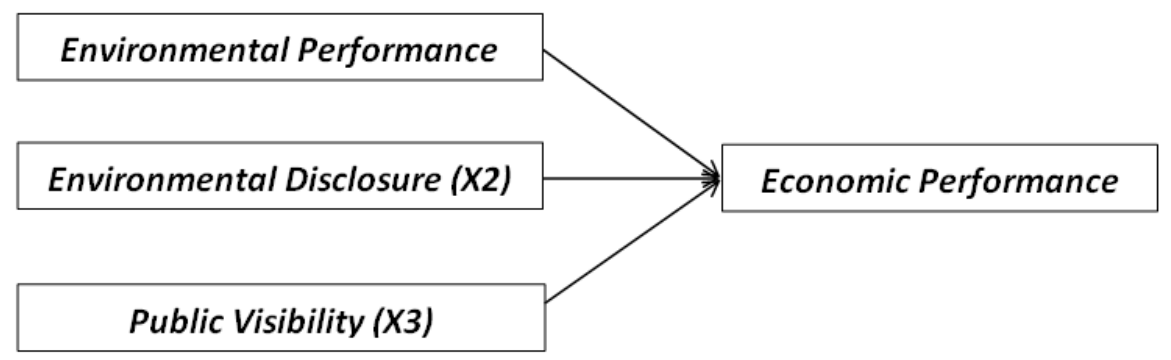

H1: Environmental Performance positive effect on the Economic Performance;

H2: Environmental Disclosure positive effect on the Economic Performance;

H3: Public Visibility positive effect on the Economic Performance. 


\section{METHODS OF RESEARCH}

Population, Sample and Sample-making techniques. This study uses documentary method of data collection. According Bungin (2005: 144), documentary method is a method used to explore the historical data. In this study, the majority of reports in the form of data, be it financial statements (to determine the economic performance measured by ROA), the company's annual reports to find out environmental disclosure (disclosure environment), as well as the results of PROPER assessment (to determine the environmental performance assessment).

The type of data in this research is quantitative data. The data used in this research is secondary data using documentation method that uses the data collected from the library, books, and the Internet. Besides using the data in the form of financial statements and annual reports collected from www.idx.co.id, list of environmental performance assessment ratings derived from www.menlh.go.id/proper in 2015-2016,

The population used in this study is all manufacturing companies listed in Indonesia Stock Exchange. This study uses the population according to the criteria specified by purposive sampling method with the criteria that are used as follows:

- Mining companies listed in Indonesia Stock Exchange and published in the Annual Financial Report 2015-2016;

- Noted as issuers continuously (never encountered delisting);

- Presenting all the data used.

Variable Operational Definition of Research. The dependent variable in this study is economic performance. Economic performance will be measured by profitability. Profitability is a measure of the company's success in generating profits by using the resources of the company (Sudana, 2011: 22). This study uses the return on assets (ROA) for assessing economic performance.

The operational definition of each of the independent variables is as follows:

Environmental Performance by Ignatius Bondan Suratno, Darsono, Siti Mutmainah (2006) is the company's performance in creating a good environment (green). Environmental performance is measured on the achievements of the company enterprise PROPER program which is one of the efforts made by the Ministry of Environment (MOE) to promote structuring of companies in environmental management through information instruments. PROPER performance rating system includes a ranking of companies within five (5) colors will be scored in a row with the highest value of 5 for the gold color and the lowest one for black

Environmental disclosure is disclosure with the environment in a company report (Ignatius Bondan Suratno, Darsono, Siti Mutmainah, 2006).Environmental disclosure is the disclosure of information relating to the environment in the company's annual report. Environmental disclosure is measured by a score according to the criteria. Criteria for environmental disclosure CSR index is based on guidance issued by the GRI (Global Reporting Initiative).

Public Visibility is measured by the presence or absence of the media / magazines / websites / web preach environmental awareness level of the company. If during the year there is a mass media reported a good response to the environment by companies then given a score of 1 , if there is given a score of 0 .

Analysis method. The analytical tool used to test the hypothesis in this study is multiple regression analysis, as the dependent variable (economic performance) is influenced by more than one independent variable. The goal is to make an estimate that can be trusted to the value of the dependent variable, if the independent variables are known (in this study is environmental performance, environmental disclosure).

\section{RESULTS AND DISCUSSION}

From Table 1 it can be seen that the value of $R$ square of 0.279 or $27.9 \%$ variable only Economic Performance, Environmental Disclosure and Public Visibility can be explained in the Variables Economic Performance but her leftovers amounted to $72.1 \%$ influenced by 
other variables because many other variables that affect a company's Economic Performance.

According Ghozali (2009: 16), F statistical test indicates whether all the independent variables included in the model have jointly influence on the dependent variable. The hypothesis can be tested by using analysis of variance (ANOVA).

Table 1 - Model Summary

\begin{tabular}{|c|c|c|c|c|c|}
\hline Model & $\mathrm{R}$ & $\mathrm{R}$ Square & Adjusted R Square & Std. Error of the Estimate & Durbin-Watson \\
\hline 1 &, $281 \mathrm{a}$ &, 279 &, 057 & 245.90100 & 1.432 \\
\hline
\end{tabular}

Table 2 - ANOVA Test

\begin{tabular}{|c|c|c|c|c|c|c|}
\hline \multicolumn{7}{|c|}{ ANOVA $^{\mathrm{a}}$} \\
\hline & & Sum of Squares & df & Mean Square & $\mathrm{F}$ & Sig. \\
\hline \multirow{3}{*}{1} & Regression & 662066,805 & 3 & 220688,935 & 3,650 &, $014^{\circ}$ \\
\hline & Residual & 7739814,454 & 128 & 60467,300 & & \\
\hline & Total & 8401881,260 & 131 & & & \\
\hline
\end{tabular}

\begin{tabular}{|c|c|c|c|c|c|c|}
\hline \multicolumn{7}{|c|}{ Coefficients $^{\mathrm{a}}$} \\
\hline \multirow[t]{2}{*}{ Mod } & & \multicolumn{2}{|c|}{ Unstandardized Coefficients } & \multirow{2}{*}{$\begin{array}{c}\text { Standardized } \\
\text { Coefficients } \\
\text { Beta } \\
\end{array}$} & \multirow[t]{2}{*}{$\mathrm{t}$} & \multirow[t]{2}{*}{ Sig. } \\
\hline & & $\mathrm{B}$ & Std. Error & & & \\
\hline \multirow{4}{*}{1} & (Constant) & $-148,235$ & 131,169 & & $-1,130$ & 261 \\
\hline & $\mathrm{x} 1$ & 86,836 & 46,523 & , 165 & 1,867 &, 064 \\
\hline & $\mathrm{x} 2$ & $-347,628$ & 170,386 &,- 202 & $-2,040$ &, 043 \\
\hline & $\mathrm{x} 3$ & 126,157 & 48,615 & 250 & 2,595 &, 011 \\
\hline
\end{tabular}

The test results using ANOVA with $F$ test shows the calculated $F$ value of 3.650 with a significance value of 0.014 . Due to the significance value less than alpha (5\%), then the conclusion is variable environmental performance (Environmental performance), environmental disclosure (disclosure environment), and public visibility together significantly affect the performance of economic variables (economic performance).

Environmental Performance. Based on $t$ test, it is known that the value of the significance of environmental performance (environmental performance) as measured by PROPER above 0.05 or a total of 0,064 so it can be said that the environmental performance negatively affect economic performance. Thus the first hypothesis $(\mathrm{H} 1)$, which states that environmental performance has a significant positive relationship to economic performance declined. These results are contrary to research conducted by Xingle Longa et al (2017), Sara Segura (2017), and Lois Mahoney et al (2017). This is because,. Not all customers could see PROPER score in the annual report.

Environmental Disclosure. Based on t test, it is known that the value of the significance of environmental disclosure (disclosure environment) below 0.05 is 0.043 with a negative coefficient so that it can be said environmental disclosure significant negative effect on economic performance (economic performance). Thus the second hypothesis $(\mathrm{H} 2)$ which states that environmental disclosure has a significant positive relationship to economic performance declined in terms of direction. This study supports the research that has been done by Norhasimah Md Nor et al (2016), but contrary to research conducted by Yan Qiu (2014).

According to Md Nor Norhasimah et al (2016), there are two reasons why the effect was not significant. The relationship between sustainable development commitments is 
illustrated through environmental disclosure score, and profitability is very low, making it difficult to detect. Research conducted by Norhasimah Md Nor et al (2016) conclude that although the company is causing a lot of pollution environmental disclosure, transparency level of activity They may not adequately describe its sustainability commitments of the company.

The results of this study confirm that environmental disclosure in annual reports less effectively unreadable by stakeholders. It is possible that for information on the compliance of the company to meet its legal obligations relating to the environment, stakeholders tend to look through other media are more easily understood, rather than reading lengthy annual report.

Influential environmental disclosure on economic performance but reversed direction from the hypothesis needs to get special attention. The more items disclosed by the company's environmental, economic performance actually declined. This indicates that environmental disclosure in the notes to the financial statements, the message is not delivered effectively by the reader. Other factors that are negative (eg, poor product quality) possible major cause of declining sales, and in this case the environmental activities of the company cannot help to improve economic performance.

Public Visibility. Based on test, it is known that the value of the significance of Public Visibility below 0.05 or a total of 0,011 so it can be said public visibility significant effect on economic performance (economic performance). Thus the third hypothesis $(\mathrm{H} 3)$, which states that public visibility have a significant positive correlation to economic acceptable performance. This study supports the research that has been conducted by Jun Cheng et al (2018).

Not all customers could see PROPER score, as well as the Environmental Disclosure via the annual report can be rarely touched by the customer. Then the media become the most powerful tool to proclaim the company's environmental activities to customers because this medium has great potential to be read or seen by the customer. Coverage by great media can influence the opinion of the customer to remain loyal or will move to the company committed to the environment (June Cheng et al, 2018).

\section{CONCLUSION}

Environmental performance as measured using the PROPER proved not significantly affects the economic performance measured by ROA (return on assets). This is because not all customers could see PROPER score in the annual report.

Environmental disclosure was measured using BAPEPAM. The results of this study stated that environmental disclosure significant negative effect on economic performance. Disclosure of the environmental activities of the company but not matched by the quality of the product, causing a negative influence between environmental performance with economic performance.

Public visibility measured from the news in the online media has a significant influence on economic performance (economic performance). Media become the most powerful tool to proclaim the company's environmental activities to customers because this medium has great potential to be read or seen by the customer. Coverage by great media can influence the opinion of the customer to remain loyal or will move to the company committed to the environment.

\section{REFERENCES}

1. Aishah Shaiful Bahari.2016. The Effects of Environmental Disclosure on Financial Performance in Malaysia.

2. Anshori, Muslich and Sri Iswati. 2009. Quantitative Research Methods. Surabaya: Airlangga University Press.

3. Atmaja. June 5th, 2013. WALHI: In 2013 Disaster from Environmental Degradation Occurs in All Provinces, (Online) (http://satuharapan.com, Accessed 19 March 2015). 
4. Chariri, Anis, and Imam Ghozali. 2007. Accounting Theory. Faculty of Economics: University of Diponegoro.

5. Dapeng Liang. 2016. Does the environmental management capability of Chinese industrial firms improve the contribution of corporate environmental performance to economic performance?

6. David C. Broadstock.2017. Voluntary disclosure, greenhouse gas emissions and business performance: Assessing the first decade of reporting.

7. Deegan, C \& Rankin, M. 1997. "The Materiality of Environmental Information to Users of Annual Report". Accounting, Auditing, and Accountability Journal, Vol. 10, No. 4, pp 562583.

8. Deegan, C., Rankin, M. and Tobin, J. 2002 "An examination of the corporate social and environmental disclosures of BHP from 1983 to 1997: A test of legitimacy theory". Accounting, Auditing \& Accountability Journal, Vol. 15 Iss: 3, pp.312 - 343

9. Ghozali, Imam. 2009. Applications Multivariate Analysis with SPSS Program. Fourth printing. Semarang: Diponegoro University Publishers Agency.

10. Hansen. Managerial Accounting, 8th Ed, Salemba Four: Jakarta.edisi 7 books 2, 2009.

11. Ingram, R. and Frazier, K. 1980. "Environmental Performance and Corporate Disclosure". Journal of Accounting Research. Vol. 18. pp. 612-622.

12. Ismail Sila. 2017. The impact of environmental, social and governance dimensions of corporate social responsibility: Australian evidence.

13. June Cheng.2018. The effects of public attention on the environmental performance of high-polluting firms: Based on big data from a web search in China.

14. Lois Mahoney.2017. Corporate Social and Environmental Performance and Their Relation to the Financial Performance and instutional Ownership: Empirical Evidence on the Canadian Firms.

15. Moneva, J. 2010. "Corporate Environmental and Financial Performance: A Multivariate Approach". Industrial Management \& Data Systems, Vol. 110, No. 2, pp. 193-210.

16. Md Norhasimah Nor.2016. The Effects of Environmental Disclosure on Financial Performance in Malaysia.

17. Article 47 of Law No. 40 Year 2007 regarding Limited Liability Company.

18. Article 66 Paragraph 2 of Act No. 40 Year 2007 regarding Limited Liability Company.

19. Environment Minister Regulation No. 07 Year 2008 on Program Performance Rating In Environmental Management.

20. Purwanto. 2000. "Environmental Performance Measurement". http://andietri.tripod.com/ (Accessed on November 23, 2014).

21. Qudratullah, Mohammad Farhan. 2013. The Theory Applied Regression Analysis, Case, and Applications with SPSS. Yogyakarta: Andi.

22. Sara Segura. 2017. Environmental versus economic performance in the EU ETS from the point of view of policy makers: a statistical analysis based on copulas

23. Sarumpaet, S. 2005. "The Relation between Environmental Performance and Financial Performance Among Indonesian Companies". SNA VIII Solo. September 15 to 16.

24. Sudana, 2011. Corporate Financial Management: Theory \& Practice. Jakarta: Erland.

25. Sunyoto, Danang. 2011. The SPSS Practice for Case. Yogyakarta: Noble

26. Wibisono, Joseph. 2007. "Dissecting Concepts and Applications Corporate Social Responsibility". Fascho Publishing. Jatim

27. Widioatmodjo, Sawidji. 2004. How Healthy Investment in Capital Markets. Jakarta.

28. Xingle Longa et al .2017. Environmental innovation and its impact on economic and environmental performance: Evidence from Korean-owned firms in China.

29. Yan Qiu.2014. Environmental and social disclosures: Link with corporate financial performance.

30. Yi-Chun Chen.2017. The Effect of Mandatory CSR Disclosure on Firm ProPtability and Social Externalities: Evidence from China

31. Yingjun Lu. 2014. Stakeholders' power, corporate characteristics, and social and environmental disclosure: Evidence from China. 